\title{
Volatile Organic Compounds Role in Selective Pollinator Visits to Commercial Melon Types
}

\author{
Nayanny de S. Fernandes ${ }^{1}$, Francisca Aliny N. Silva ${ }^{2}$, Fernando A. S. de Aragão ${ }^{2}$, \\ Guilherme J. Zocolo ${ }^{2}$ \& Breno M. Freitas ${ }^{1}$ \\ ${ }^{1}$ Departamento de Zootecnia, Universidade Federal do Ceará, Fortaleza, Brazil \\ ${ }^{2}$ Embrapa Agroindústria Tropical, Fortaleza, Brazil \\ Correspondence: Nayanny Fernandes, Departamento de Zootecnia, Universidade Federal do Ceará, Fortaleza, CE, \\ 60021-970, Brazil. Tel: 55-853-366-9220. E-mail: nayanny@msn.com
}

Received: November 11, 2018

Accepted: December 13, 2018

Online Published: February 15, 2019

doi:10.5539/jas.v11n3p93

URL: https://doi.org/10.5539/jas.v11n3p93

The research is partly financed by the National Institute of Science and Technology-INCT BioNat, grant 465637/2014-0, Brazil and the Coordenação de Aperfeiçoamento de Pessoal de Nivel Superior-Brasil (CAPES)-Finance Code 001.

\begin{abstract}
Pollination is essential for food production in the world, but in pollinator-dependent crops it relies on the attraction of pollinators to flowers. However, crop varieties vary in their attractiveness to flower visitors and volatile compounds emitted by flowers may play a significant role in attracting or repelling pollinators. Here, we investigated the volatile organic compounds (VOCs) present in both male and hermaphrodite flowers of five commercial types of melon Cucumis melo (Cantaloupe, Charentais, Galia, Piel de sapo and Yellow), and their role in attracting or repelling Apis mellifera foragers. We found significant variation in the identity and proportion of these chemical compounds produced by both melon types and flower genders and observed significant positive and negative correlations between the amount of D-Limonene and Benzaldehyde (bee attractants) and $\alpha$-Pinene (bee repellent), respectively, to the number of bee visits to flowers particularly in the Cantaloupe type and hermaphrodite flowers, the most visited ones. Our results suggest that differences in the composition of melon floral VOCs and the proportion of the different compounds play significant role in the number of visits by $A$. mellifera with possible implications to pollination and fruit yield. It also implies to the perspective of breeding varieties more attractive to pollinators through the selection of flower lines richer in bee-attractant and/or poorer in bee-repellent volatiles.
\end{abstract}

Keywords: crop pollination, Cucumis melo, floral volatiles, flower choice, $\alpha$-Pinene

\section{Introduction}

Pollination is an essential ecosystem service to crop production worldwide, contributing to the yield (quantity and/or quality) of most crops (Klein et al., 2007; Ricketts et al., 2008; IPBES, 2016) and food security for providing essential micronutrients to human health (Lautenbach et al., 2012; Chaplin-Kramer et al., 2014). But low productivity in pollinator-dependent crops has been related to a reduction in the number and diversity of pollinators (Garibaldi et al., 2013; Freitas et al., 2014), leading to inadequate pollination both in quantitative and qualitative terms (Aizen \& Harder, 2007; Garibaldi et al., 2011). Practices associated with agricultural intensification such as deforestation, large field sizes, clean cultivation and high use of pesticides have been linked to pollination deficits and decline in crop production (Freitas et al., 2009; Potts et al., 2010; Rundlöf et al., 2015), while traits inherent to the crop itself such as the ability to attract pollinators have been overlooked.

Pollinator-dependent plants have evolved a variety of ways to sign rewards to floral visitors, thus attracting their pollinators (Varassin \& Amaral-Neto, 2014; Farré-Armengol, 2015). Floral traits such as size, shape, color, petal texture, movement and even electric fields have been studied and acknowledged to play roles in the recognition and attraction of pollinators to flowers (Dafni \& Kevan, 1997; Whitney et al., 2009, 2013; Alcorn; Whitney \& Glover, 2012; Clarke et al., 2013; Myczko et al., 2015). These strategies separately or together can influence the preference and foraging behavior of floral visitors (Wright \& Schiestl, 2009). But the visual and olfactory 
display seem to be the most relevant floral traits ruling pollinator attraction (Kunze \& Gumbert, 2001; Chittka \& Raine, 2006) and many floral visitors learn to distinguish the best rewarding flowers by their characteristic odor (Chittka, Thomson, \& Waser, 1999). Even so, studies of flower-pollinator interaction have focused mostly in the visual floral traits and ecological approaches neglecting the role of flower volatiles for the attractiveness of crops to pollinators (Raguso, 2008; Klatt et al., 2013).

The floral aroma is constituted by a great variety of volatile organic compounds (VOCs) (Song et al., 2014; Soto et al., 2015). VOCs are synthesized, produced from petroleum or derived from natural compounds, mainly plants. Organic fragrances and volatile compounds of plants have been used as food additives, medications and aromatherapy throughout the ages (Yamada et al., 2015), are also used in the production of perfumes and essences (Vankar, 2004). Some of these VOCs may be toxic to humans, for example toluene widely used in the manufacture of glues, paints and cleaning solvents (Filley, Halliday, Kleinschmidt-DeMasters, 2004; Pascual \& Bustamante, 2011). They play important role in the interactions between plants and biotic and abiotic factors (Vivaldo et al., 2017), being involved in a range of ecological functions such as defense against pathogens and insects (Song \& Ryu, 2013); pollinator attraction (Suchet et al., 2011; Farré-Armengol et al., 2015); communication between plants (Ueda, Kikuta, \& Matsuda, 2012); tolerance to environmental stress (Holopainen \& Gershenzon, 2010) and defense of predators (Arimura, Matsui, \& Takabayashi, 2009; War et al., 2012).

VOCs emission by flowers is quantitatively and qualitatively variable, from species that emit weak and simple aromas to those that produce strong and complex VOCs (Parachnowitsch, Raguso, \& Kessler, 2012; Farré-Armengol, 2015). Some VOCs may exert a defense function, repelling those animals that may cause damage to the plant or its flowers (Pichersky \& Gershenzon, 2002; Schiestl, 2010), while other compounds act as attractants for pollinators (Dudareva \& Pichersky, 2006; Raguso, 2008). Indeed, the role of VOCs in the attractiveness of flowers to pollinating bees has been reported (Wright \& Schiest, 2009; Filella et al., 2013; Soto et al., 2015; Ceuppens et al., 2015). In general, attractant VOCs can assist the pollinator in both locating and recognizing the flower (Majetic, Raguso, \& Ashman, 2009), as well as associating them with the quantity and quality of floral resources (Dudareva \& Pichersky, 2006; Howell \& Alarcón, 2007).

In agriculture, most crops grown nowadays are the product of plant breeding programs carried out by man with the purpose of selecting desired traits such as higher productivity, larger fruits, higher oil content in seeds, pest and/or disease tolerance, etc., but usually with no concern about floral traits related to pollinator attraction (Klatt et al., 2013; Bomfim et al., 2015). As a consequence, a great number of varieties, types, cultivars and hybrids of most cultivated plant species have been developed around the world but with little knowledge of their ability to attract pollinators, and the attractiveness of a crop species is commonly assumed to be similar among its agronomic varieties. Actually, pollinators seem to be capable of distinguishing among crop varieties and reject the less attractive ones as shown for sunflower (Pham-Delegue et al., 1989), canola (Wright, Skinner, \& Smith, 2002), strawberries (Klatt et al., 2013; Ceuppens et al., 2015) blueberries (Rodriguez-Saona et al., 2011) and melon (Fernandes, 2017), and recent studies suggest that floral volatiles have a major role in this choice (Pham-Delegue et al., 1989; Wright; Skinner, \& Smith, 2002; Rodriguez-Saona et al., 2011; Klatt et al., 2013). This behavior could be expected because the odor produced by a flower is a blend of the volatiles found in the pollen, nectar, petals, sepals and other floral structures which can vary even from male to hermaphrodite to female flowers of the same plant (Farré-Armengol et al., 2015).

In the Cucurbitaceae family, the role of VOCs has been studied in some species, such as zucchini-Cucurbita pepo L. (Granero et al., 2004), wild squash-Cucurbita pepo subsp. texana (Ferrari et al., 2006) and pumpkin-Cucurbita moschata Duchesne (Andrews, Theis, \& Adler, 2007). However, melon (Cucumis melo L.), the third most cultivated curcubit in the world and whose lack of adequate biotic pollination can lead to a reduction of $90 \%$ in fruit production (Klein et al., 2007; FAO, 2018) still lacks studies on its VOCs and the role they play in attracting pollinators. Despite evident differences in the fruit size and appearance between agronomic types (Pitrat, Hanelt, \& Hammer, 2000; Crisóstomo \& Aragão, 2013), the melon flowers look similar and studies on melon pollination have focused in identifying potential pollinators, number of visits to set a flower or number of honeybee colonies per area (Ribeiro et al., 2015; Tschoeke et al., 2015), while the attractiveness of flowers to pollinators remains unheeded.

A variety of bee species have been reported as efficient pollinators of melon flowers, from solitary and parasocial species such as Xylocopa grisescens and bees of the Halictidae Family (Coelho et al., 2012) to social stingless bees such as Trigona carbonaria (Kouonon et al., 2009), Trigona spinipes (Kiill et al., 2011) and Scaptotrigona sp. (Bezerra, 2014), but honey bee (Apis mellifera) is the managed species used globally in the pollination of this crop (Mussen \& Thorp, 2003; Hoz, 2007; Reyes-Carrillo et al., 2007; Sousa et al., 2009; Kiill et al., 2014; Bomfim et al., 2016). However, the recent study by Fernandes (2017) has showed that A. mellifera can 
discriminate between melon flowers and presents differentiated visitation rates to distinct agronomic types of melon with potential implications to crop yield. We suspect that floral attractants, especially VOCs, may have played a relevant role in the flower attractiveness and discrimination by the bees in that study.

In this context, we examined the results obtained by Fernandes (2017) in respect to the VOC profile of the melon flowers aiming to (i) identify, quantify and qualify the volatile organic compounds (VOCs) produced by melon flowers; (ii) determine possible differences in the profile of volatile organic compounds (VOCs) produced according to the flower gender and agronomic types of melon; (iii) investigate possible relationships between the volatile organic compounds (VOCs) produced by the melon flowers and the observed number of floral visits of the most used pollinator of this crop, the bee Apis mellifera.

\section{Material and Methods}

\subsection{Field Experimental Design}

The study was carried out from November 2015 to February 2016 at the Experimental Field and the Natural Products Laboratory of the Brazilian Agricultural Research Corporation-Embrapa located in the municipalities of Pacajus and Fortaleza, respectively, in Ceará, NE Brazil.

The field experiment was set in a cultivated area of $625 \mathrm{~m}^{2}$ made of 20 rows, each row split in two halves, totaling 40 experimental plots. Five commercial melon types were cultivated in eight replicate plots in an entirely randomized design, and each plot comprised 25 melon plants. Each type of melon was represented by a hybrid of good commercial acceptance, Yellow (Goldex), Cantaloupe (Zelda), Piel de sapo (Ricura), Charentais (Banzai) and Galia (McLaren). The crop was cultivated accordingly to the agronomic recommendations for growing melons and pesticides were not used to prevent interferences with bee visitation to the flowers of the different melon types. When the melon plants came into bloom, two colonies of the Africanized honey bee, Apis mellifera were introduced in the experimental area to provide floral visitors. More details in the procedures regarding the crop experimental design, melon cultivation, honey bee introduction and management, and data collection on A. mellifera discrimination between melon flowers and differentiated visitation rates to the distinct agronomic types of melon are given in Fernandes (2017). Also see Figure 1.

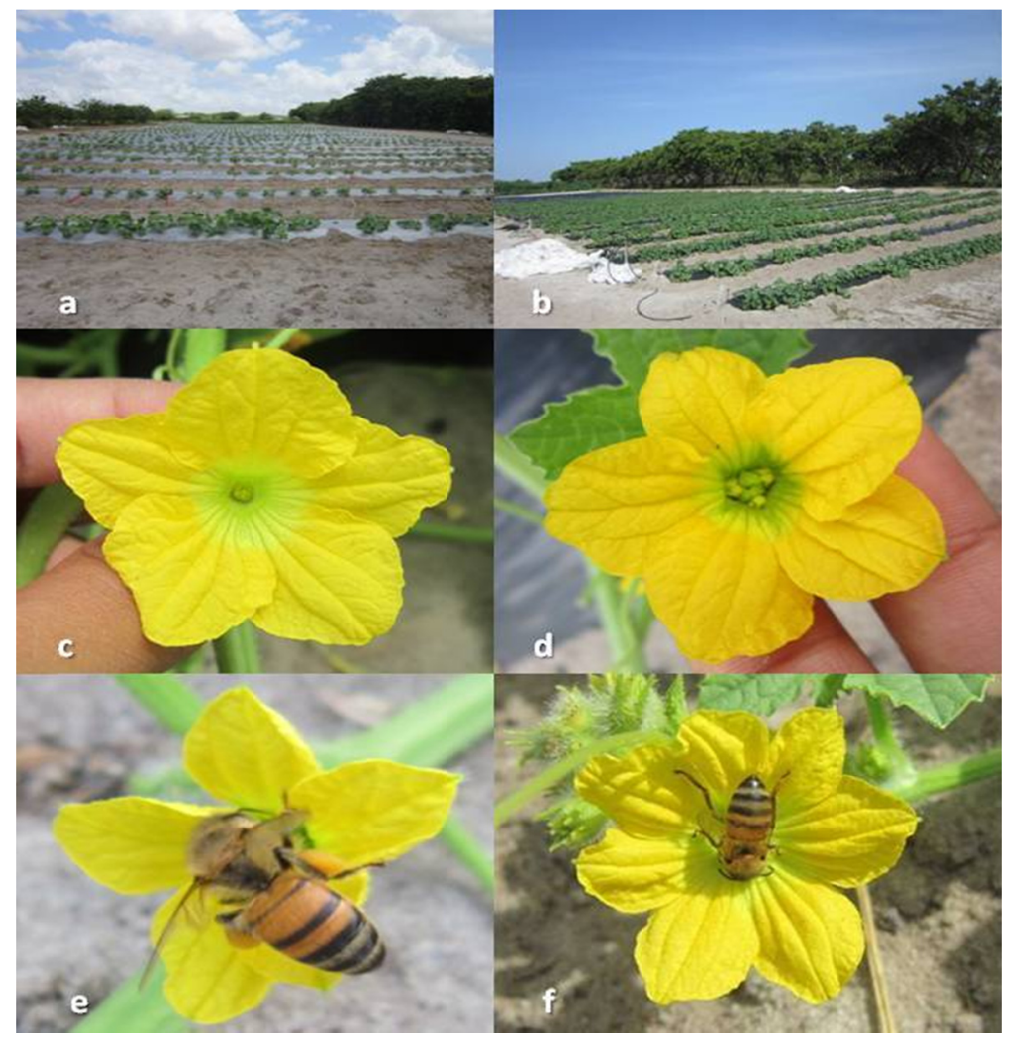

Figure 1. Experimental area with five distinct agronomic types of melon: a. general view of the young melon plants; b. melon crop at blooming; c. male melon flower; d. hermaphrodite melon flower; e. honey bee collecting pollen in a melon flower; f. honey bee collecting nectar in a melon flower 


\subsection{VOCs Extraction, Analyses, Identification and Relative Abundance}

For the extraction of the volatile organic compounds from the flowers, three male and two hermaphrodite flowers of each of the five types of melon were randomly collected in the cultivated area. The flowers were cut in the peduncle portion using gloves, scissors and tweezers, so that there was no direct manual contact with the flowers, avoiding any contamination. Then, the flowers were placed in headspace vial bottles, identified by their gender and the corresponding type of melon. The flowers were conditioned in Styrofoam boxes filled with chemical ice for approximately eight hours before taken for analysis in the Natural Products Laboratory, at Embrapa Agroindústria Tropical headquarters.

Volatile organic compounds were extracted from the flowers by the analytical headspace method, using an automatic sampler and SPME fiber support (Supelco, Bellefonte, PA, USA). Carboxene/polydimethylsiloxane fiber (CAR/PDMS), $75 \mu \mathrm{m}$ thick and $1 \mathrm{~cm}$ long, was used as the stationary phase, as suggested by Silva (2014), recently published as Silva et al. (2018). CAR/PDMS fiber was conditioned for the time suggested by the manufacturer (Supelco, Bellefonte, PA, USA) and at $10{ }^{\circ} \mathrm{C}$ lower than the temperature stated (CAR/PDMS: $290{ }^{\circ} \mathrm{C}$ for 60 minutes).

The $20 \mathrm{~mL}$ headspace flasks containing the samples were sealed with a silicone septum/PTFE (Supelco, Bellefonte, PA, USA) and left in the furnace for SPME of the apparatus at $35^{\circ} \mathrm{C}$ for 15 minutes to concentrate the volatiles followed by their capture by the exposure of the SPME CAR/PDMS fiber for a period of 30 minutes at $35^{\circ} \mathrm{C}$ without agitation. The adsorbed compounds were identified and semi-quantified by gas chromatography coupled to mass spectrometry (GC-MS), in duplicate.

For the volatile analyzes, a 7890B GC System gas chromatograph (Agilent Technologies Spain, S.L., Madrid, Spain) was coupled to the mass spectrometer model 5977A MSD (Agilent Technologies Spain, S.L., Madrid, Spain). The male and hermaphrodite flower compounds of the five different types of melon were separated using a $60 \mathrm{~m} \times 0.25 \mathrm{~mm} \times 0.25 \mu \mathrm{m}$ DB 5MS capillary column (Agilent J \& WGC Columns, Santa Clara, CA, USA). The SPME CAR/PDMS fiber was maintained in the injector at $240{ }^{\circ} \mathrm{C}$ for three minutes for desorption of the compounds and then the fiber was conditioned for 10 minutes before the next collection.

The volatiles were desorbed in splitless mode and gas helium was used as the drag gas with a flow of $1 \mathrm{~mL} \mathrm{~min}^{-1}$. The temperature program applied was isotherm for 4 minutes at $40{ }^{\circ} \mathrm{C}$, raised to $80{ }^{\circ} \mathrm{C}$ at a rate of $2.5{ }^{\circ} \mathrm{C}$ minutes ${ }^{-1}$, and then increased to $110^{\circ} \mathrm{C}$ at a rate of $5{ }^{\circ} \mathrm{C}_{\text {minutes }}^{-1}$, and finally increased to $220{ }^{\circ} \mathrm{C}$ at a rate of $10^{\circ} \mathrm{C}^{-1}$ minutes $^{-1}$ and held for 13 minutes, totaling 50 minutes of running time. The transfer line temperature was $280{ }^{\circ} \mathrm{C}$ and that of the detector was $150{ }^{\circ} \mathrm{C}$. The mass spectra were obtained using a electron-ionization (EI) quadripolar analyzer system at 70 electron-volts $(\mathrm{eV})$ and a mass acquisition interval of 50-600 Da.

The compounds were identified by comparing their mass spectra with those contained in the NIST library 2.0, 2012 (National Institute of Standards and Technology, Gaithersburg, Md, USA) and/or by calculating the Kovats index for a series of saturated alkanes (C7-C30) (Supelco, 49451-U, Bellefonte, PA, USA). Then, the results were compared with the IKs presented in the literature to confirm the identification of the compounds (Adams, 2007) and the results of the analyzes were presented in relative abundance.

Data obtained on the identity and relative abundance were presented in a table and submitted to correlation analyses with the number of Apis mellifera visits to flowers of the distinct melon flowers, according to the findings of Fernandes (2017).

\section{Results}

Analyses of the flower odors of the five different melon types allowed to determine the identification and relative percentages of VOC area of male and hermaphrodite flowers totaling 37 different volatile compounds (Table 1). 
Table 1. Chemical composition of the volatile organic compounds of male (M) and hermaphrodite (H) flowers of five commercial types of melon (Cucumis melo L.) by HS-SPME/GC-MS

\begin{tabular}{|c|c|c|c|c|c|c|c|c|c|c|}
\hline \multirow{2}{*}{ Volatile Compounds } & \multicolumn{2}{|c|}{ Yellow } & \multicolumn{2}{|c|}{ Cantaloupe } & \multicolumn{2}{|c|}{ Charentais } & \multicolumn{2}{|c|}{ Galia } & \multicolumn{2}{|c|}{ Piel de sapo } \\
\hline & $\bar{M}$ & $\mathrm{H}$ & $\mathrm{M}$ & $\mathrm{H}$ & $\mathrm{M}$ & $\mathrm{H}$ & $\bar{M}$ & $\mathrm{H}$ & $\mathrm{M}$ & $\mathrm{H}$ \\
\hline 1-Penten-3-ol & 0.00 & 0.00 & 0.74 & 1.21 & 0.00 & 0.00 & 0.00 & 0.00 & 0.00 & 0.85 \\
\hline Benzyl alcohol & 0.00 & 0.00 & 2.73 & 9.19 & 0.00 & 0.00 & 0.00 & 0.00 & 0.00 & 0.00 \\
\hline 3-Hexen-1-ol & 0.00 & 0.00 & 0.00 & 1.69 & 0.00 & 0.00 & 0.00 & 0.00 & 0.00 & 0.00 \\
\hline 1-Butanol, 2-methyl- & 0.00 & 0.00 & 0.00 & 0.00 & 0.00 & 3.30 & 0.00 & 0.00 & 0.00 & 0.00 \\
\hline - - - Alcohols - - & 0.00 & 0.00 & 3.47 & 12.09 & 0.00 & 3.30 & 0.00 & 0.00 & 0.00 & 0.85 \\
\hline Benzaldehyde & 0.00 & 6.61 & 19.83 & 27.43 & 0.00 & 0.00 & 1.14 & 2.02 & 0.00 & 0.00 \\
\hline 2-Butenal, 2-methyl- & 0.00 & 0.00 & 0.00 & 0.00 & 0.00 & 8.68 & 0.00 & 7.59 & 0.00 & 5.29 \\
\hline Heptanal, 2-methyl- & 0.00 & 0.00 & 0.00 & 0.00 & 0.00 & 0.00 & 0.00 & 0.00 & 0.00 & 0.64 \\
\hline - - - Aldehydes - - & 0.00 & 6.61 & 19.83 & 27.43 & 0.00 & 8.68 & 1.14 & 9.61 & 0.00 & 5.93 \\
\hline Octane, 2,3,6-trimethyl- & 0.00 & 0.29 & 0.00 & 0.00 & 0.00 & 0.00 & 0.00 & 0.00 & 0.00 & 0.00 \\
\hline Styrene & 0.00 & 0.00 & 0.00 & 0.46 & 0.00 & 0.00 & 0.00 & 0.42 & 0.00 & 0.00 \\
\hline - - - Hydrocarbons - - - & 0.00 & 0.29 & 0.00 & 0.46 & 0.00 & 0.00 & 0.00 & 0.42 & 0.00 & 0.00 \\
\hline Acetophenone & 0.00 & 0.00 & 0.20 & 0.45 & 0.00 & 0.00 & 0.00 & 0.00 & 0.00 & 0.00 \\
\hline - - - Ketones - - - & 0.00 & 0.00 & 0.20 & 0.45 & 0.00 & 0.00 & 0.00 & 0.00 & 0.00 & 0.00 \\
\hline Methyl $\alpha$-methylbutanoate & 0.00 & 2.41 & 0.00 & 0.00 & 0.00 & 0.00 & 0.00 & 1.84 & 0.00 & 0.00 \\
\hline Methyl 2-methylbutanoate & 0.00 & 0.00 & 0.00 & 0.00 & 0.00 & 2.33 & 0.00 & 0.00 & 0.00 & 0.00 \\
\hline Methyl benzoate & 0.00 & 0.00 & 5.50 & 5.40 & 0.00 & 0.00 & 0.00 & 0.52 & 0.00 & 0.00 \\
\hline Methyl salicylate & 0.00 & 0.00 & 0.00 & 0.58 & 0.00 & 0.00 & 0.00 & 0.00 & 0.00 & 0.00 \\
\hline Ethyl Acetate & 0.00 & 0.00 & 0.00 & 0.00 & 0.00 & 57.07 & 0.00 & 13.13 & 0.00 & 14.59 \\
\hline Ethyl propanoate & 0.00 & 0.00 & 0.00 & 0.00 & 0.00 & 21.69 & 0.00 & 6.67 & 0.00 & 14.07 \\
\hline Ethyl 3-methylbutanoate & 0.00 & 0.00 & 0.00 & 0.00 & 0.00 & 1.02 & 0.00 & 0.92 & 0.00 & 1.97 \\
\hline Ethyl 2-methylbutanoate & 0.00 & 0.00 & 0.00 & 0.00 & 0.00 & 1.17 & 0.00 & 0.00 & 0.00 & 0.00 \\
\hline Ethyl tiglate & 0.00 & 0.00 & 0.00 & 0.00 & 0.00 & 0.35 & 0.00 & 1.57 & 0.00 & 0.00 \\
\hline Ethyl butanoate & 0.00 & 0.00 & 0.00 & 0.00 & 0.00 & 0.97 & 0.00 & 0.00 & 0.00 & 0.00 \\
\hline Ethyl benzoate & 0.00 & 0.00 & 0.13 & 0.35 & 0.00 & 0.11 & 0.00 & 1.93 & 0.00 & 0.00 \\
\hline - - - Esters - - - & 0.00 & 2.41 & 5.63 & 6.32 & 0.00 & 84.71 & 0.00 & 26.60 & 0.00 & 30.63 \\
\hline$\alpha$-Pinene & 87.20 & 70.11 & 32.19 & 25.59 & 90.31 & 3.18 & 86.54 & 50.62 & 82.05 & 52.26 \\
\hline Camphene & 1.17 & 1.00 & 0.38 & 0.38 & 0.00 & 0.00 & 1.01 & 0.57 & 1.09 & 0.58 \\
\hline o-Cymene & 0.75 & 1.05 & 2.15 & 1.51 & 0.00 & 0.00 & 0.48 & 0.45 & 0.99 & 0.60 \\
\hline Sabinene & 1.21 & 1.67 & 1.41 & 1.36 & 0.00 & 0.13 & 0.95 & 1.17 & 1.47 & 0.91 \\
\hline D-Limonene & 4.40 & 10.10 & 28.94 & 16.24 & 7.31 & 0.00 & 4.43 & 5.05 & 7.84 & 4.38 \\
\hline$\alpha$-Thujene & 0.00 & 0.88 & 0.74 & 0.93 & 0.00 & 0.00 & 0.46 & 0.00 & 0.92 & 0.33 \\
\hline$\beta$-Myrcene & 0.00 & 0.64 & 1.61 & 1.12 & 0.00 & 0.00 & 0.00 & 0.53 & 0.64 & 0.00 \\
\hline$\beta$-Thujene & 0.00 & 5.24 & 0.00 & 0.00 & 0.00 & 0.00 & 0.00 & 0.00 & 0.00 & 0.00 \\
\hline$\alpha$-Terpineol & 0.00 & 0.00 & 0.45 & 2.28 & 0.00 & 0.00 & 0.00 & 0.69 & 0.00 & 0.00 \\
\hline Terpinolene & 0.00 & 0.00 & 0.77 & 0.53 & 0.00 & 0.00 & 0.00 & 0.00 & 0.00 & 0.00 \\
\hline$\beta$-Pinene & 5.28 & 0.00 & 2.24 & 2.27 & 2.38 & 0.00 & 5.00 & 3.69 & 5.01 & 3.52 \\
\hline$\alpha$-Terpinene & 0.00 & 0.00 & 0.00 & 0.15 & 0.00 & 0.00 & 0.00 & 0.00 & 0.00 & 0.00 \\
\hline endo-Borneol ou Camphol & 0.00 & 0.00 & 0.00 & 0.14 & 0.00 & 0.00 & 0.00 & 0.00 & 0.00 & 0.00 \\
\hline 1-Verbenone & 0.00 & 0.00 & 0.00 & 0.17 & 0.00 & 0.00 & 0.00 & 0.00 & 0.00 & 0.00 \\
\hline Eucalyptol & 0.00 & 0.00 & 0.00 & 0.00 & 0.00 & 0.00 & 0.00 & 0.59 & 0.00 & 0.00 \\
\hline $\begin{array}{l}2(3 \mathrm{H}) \text {-Benzofuranone, } \\
\text { hexahydro-3a,7a-dimethyl-, cis- }\end{array}$ & 0.00 & 0.00 & 0.00 & 0.57 & 0.00 & 0.00 & 0.00 & 0.00 & 0.00 & 0.00 \\
\hline - - - Terpenes - - - & 100.00 & 90.69 & 70.87 & 53.24 & 100.00 & 3.30 & 98.86 & 63.37 & 100.00 & 62.59 \\
\hline Total & 100.00 & 100.00 & 100.00 & 100.00 & 100.00 & 100.00 & 100.00 & 100.00 & 100.00 & 100.00 \\
\hline
\end{tabular}

The volatile chemical compounds identified were grouped into six categories based on the chemical structure: alcohols (4), aldehydes (3), hydrocarbons (2), ketones (1), esters (11) and terpenes (16) (Table 1). However, the 
greatest number of volatile compounds found in the male flowers of the five melon types belong to the terpene group, especially in the male flowers of the types Yellow, Charentais and Piel de sapo, which presented $100 \%$ of VOCs belonging to this chemical group. The exceptions were the Galia type that besides the terpenes also emitted a compound of the aldehyde group and, above all, the Cantaloupe type that presented the greatest variety of compounds, emitting terpernes and compounds of several other chemical groups such as alcohol, aldehyde, ketone and ester (Table 1).

There was also a predominance of VOCs of the terpene group in the hermaphrodite flowers, especially in the hermaphrodite flower of the Yellow type, which presented the highest percentage of terpenes in its composition with $90.69 \%$. The exception was the Charentais type that presented hermaphrodite flowers with $84.71 \%$ of compounds belonging to the ester group. We can also highlight the variation in the number of volatile compounds among the floral genders. In all five melon types the hermaphrodite flowers were richer in VOCs than the male flowers, and the hermaphrodite flowers of the Cantaloupe type also presented the greatest variety of VOCs among flowers of all melon types (Table 1).

The dominance of terpenes in VOCs of melon flowers was due to $\alpha$-Pinene, the only volatile compound common to all types of melon and flower genders, being also the most predominant compound in the different types of melon (25.59 to $90.31 \%$ ), except for the hermaphrodite flowers of the Cantaloupe, in which Benzaldehyde prevailed, and the Charentais type, where Ethyl Acetate was the most abundant compound (Table 1). The $\alpha$-Pinene was followed by Ethyl Acetate and D-Limonene, second and third in relative abundance, though Ethyl Acetate was present only in hermaphrodite flowers of the Charentais, Galia and Piel de sapo types (Table 1).

According to Fernandes $(2017)$, significant difference $(p<0.05)$ was found for the number of honey bees observed foraging among the male or the hermaphrodite flowers of the five types of melon. Independently of the flower gender, the greatest number of visits was recorded in the Cantaloupe type $(p<0.05)$, followed by the Yellow and Piel de sapo types, which did not differ between them, but differing $(\mathrm{p}<0.05)$ from other types of melon, Charentais and Galia, which also showed no significant difference between them. Correlation analyses between these flower visits and the chemical groups showed significant positive correlation of aldehydes and significant negative correlation of terpenes with bee visits to male flowers (Tables 2 and 3) and only significant positive correlations of aldehydes and alcohols with A. mellifera visits to hermaphrodite flowers (Tables 4 and 5). Also, out of the 37 VOCs found in melon flowers, six compounds present significant positive or negative correlations, probably being responsible for the attraction or repellency to the pollinator (Tables 6-9).

Table 2. Correlation matrix between the number of Apis mellifera visits and the chemical groups identified in male flowers (VMF) in five commercial types of melon

\begin{tabular}{l|lll|}
\multicolumn{2}{l}{ Correlation Matrix } & & \\
& VMF & Aldeihydes & Terpenes \\
\hline VMF & 1.00 & 0.905 & -0.909 \\
Aldehydes & 0.905 & 1.00 & -1.00 \\
Terpenes & -0.909 & -1.00 & 1.00 \\
\hline
\end{tabular}

Note. Values in white cells denote significant correlations at $\mathrm{p}<0.05$.

Table 3. P-values matrix of the correlation between the number of Apis mellifera visits and the chemical groups identified in male flowers (VMF) in five commercial types of melon

\begin{tabular}{l|lll|} 
P-Values Matrix & & & \\
& VMF & Aldehydes & Terpenes \\
\hline VMF & 1.00 & 0.035 & 0.032 \\
\hline Aldehydes & 0.035 & 1.00 & 0.00 \\
Terpenes & 0.032 & 0.00 & 1.00 \\
\hline
\end{tabular}

Note. Values in white cells denote significant correlations at $\mathrm{p}<0.05$. 
Table 4. Correlation matrix between the number of Apis mellifera visits and the chemical groups identified in hermaphrodite flowers (VHF) in five commercial types of melon

\begin{tabular}{|c|c|c|c|c|c|c|}
\hline \multicolumn{7}{|c|}{ Correlation Matrix } \\
\hline & $V H F$ & Alcohols & Aldehydes & Hydrocarbons & Esters & Terpenes \\
\hline VHF & 1.000 & 0.900 & 0.880 & 0.379 & -0.114 & -0.272 \\
\hline Alcohols & 0.900 & 1.000 & 0.960 & 0.377 & -0.159 & -0.275 \\
\hline Aldehydes & 0.880 & 0.960 & 1.000 & 0.612 & -0.335 & -0.100 \\
\hline Hydrocarbons & 0.379 & 0.377 & 0.612 & 1.000 & -0.699 & 0.478 \\
\hline Esters & -0.114 & -0.159 & -0.335 & -0.699 & 1.000 & -0.904 \\
\hline Terpenes & -0.272 & -0.275 & -0.100 & 0.478 & -0.904 & 1.000 \\
\hline
\end{tabular}

Note. Values in white cells denote significant correlations at $\mathrm{p}<0.05$.

Table 5. P-values matrix of the correlation between the number of Apis mellifera visits and the chemical groups identified in hermaphrodite flowers (VHF) in five commercial types of melon

\begin{tabular}{|c|c|c|c|c|c|c|}
\hline \multicolumn{7}{|c|}{ P-Values Matrix } \\
\hline & VHF & Alcohols & Aldehydes & Hydrocarbons & Esters & Terpenes \\
\hline VHF & 1.000 & 0.037 & 0.047 & 0.529 & 0.855 & 0.658 \\
\hline Alcohols & 0.037 & 1.000 & 0.009 & 0.532 & 0.798 & 0.655 \\
\hline Aldehydes & 0.047 & 0.009 & 1.000 & 0.272 & 0.582 & 0.873 \\
\hline Hydrocarbons & 0.529 & 0.532 & 0.272 & 1.000 & 0.189 & 0.415 \\
\hline Esters & 0.855 & 0.798 & 0.582 & 0.189 & 1.000 & 0.035 \\
\hline Terpenes & 0.658 & 0.655 & 0.873 & 0.415 & 0.035 & 1.000 \\
\hline
\end{tabular}

Note. Values in white cells denote significant correlations at $\mathrm{p}<0.05$.

Table 6. Correlation matrix between the number of Apis mellifera visits and the volatiles organic compounds identified in male flowers (VMF) in five commercial types of melon

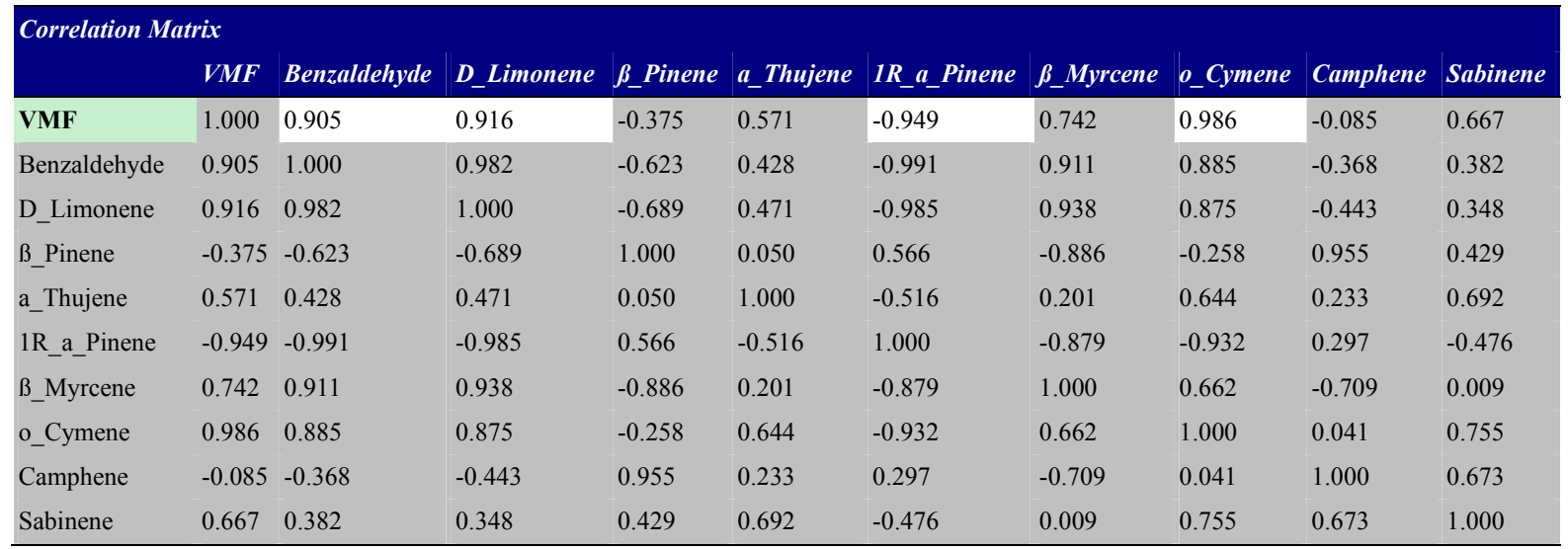

Note. Values in white cells denote significant correlations at $\mathrm{p}<0.05$. 
Table 7. P-values matrix of the correlation between the number of Apis mellifera visits and the volatiles organic compounds identified in male flowers (VMF) in five commercial types of melon

\begin{tabular}{|c|c|c|c|c|c|c|c|c|c|c|}
\hline \multicolumn{11}{|c|}{ P-Values Matrix } \\
\hline & $V M F$ & Benzaldehyde & D_Limonene & $\beta_{-}$Pinene & a_Thujene & 1R_a_Pinene & B_Myrcene & o_Cymene & Camphene & Sabinene \\
\hline VMF & 1.000 & 0.035 & 0.029 & 0.534 & 0.315 & 0.014 & 0.151 & 0.002 & 0.892 & 0.219 \\
\hline Benzaldehyde & 0.035 & 1.000 & 0.003 & 0.262 & 0.472 & 0.001 & 0.031 & 0.046 & 0.542 & 0.525 \\
\hline D_Limonene & 0.029 & 0.003 & 1.000 & 0.198 & 0.424 & 0.002 & 0.018 & 0.052 & 0.454 & 0.566 \\
\hline B_Pinene & 0.534 & 0.262 & 0.198 & 1.000 & 0.937 & 0.320 & 0.046 & 0.675 & 0.012 & 0.471 \\
\hline a_Thujene & 0.315 & 0.472 & 0.424 & 0.937 & 1.000 & 0.373 & 0.746 & 0.241 & 0.706 & 0.195 \\
\hline 1R_a_Pinene & 0.014 & 0.001 & 0.002 & 0.320 & 0.373 & 1.000 & 0.050 & 0.021 & 0.627 & 0.418 \\
\hline B_Myrcene & 0.151 & 0.031 & 0.018 & 0.046 & 0.746 & 0.050 & 1.000 & 0.223 & 0.180 & 0.988 \\
\hline o_Cymene & 0.002 & 0.046 & 0.052 & 0.675 & 0.241 & 0.021 & 0.223 & 1.000 & 0.948 & 0.140 \\
\hline Camphene & 0.892 & 0.542 & 0.454 & 0.012 & 0.706 & 0.627 & 0.180 & 0.948 & 1.000 & 0.213 \\
\hline Sabinene & 0.219 & 0.525 & 0.566 & 0.471 & 0.195 & 0.418 & 0.988 & 0.140 & 0.213 & 1.000 \\
\hline
\end{tabular}

Note. Values in white cells denote significant correlations at $\mathrm{p}<0.05$.

Table 8. Correlation matrix between the number of Apis mellifera visits and the volatiles organic compounds identified in hermaphrodite flowers (VHF) in five commercial types of melon

\begin{tabular}{|c|c|c|c|c|c|c|c|c|c|c|c|}
\hline \multicolumn{12}{|l|}{ Correlation Matrix } \\
\hline & VHF & Benzaldehyde & D_Limonene & B_Pinene & o_Cymene & B_Myrcene & Sabinene & 1_Penten_3_ol & 2_Butenal_2_methyl & a_Thujene & Ethyl_propanoate \\
\hline VHF & 1.000 & 0.850 & 0.863 & 0.216 & 0.895 & 0.656 & 0.517 & 0.907 & -0.788 & 0.892 & -0.592 \\
\hline Benzaldehyde & 0.850 & 1.000 & 0.915 & 0.016 & 0.865 & 0.889 & 0.476 & 0.682 & -0.731 & 0.747 & -0.670 \\
\hline D_Limonene & 0.863 & 0.915 & 1.000 & 0.068 & 0.987 & 0.930 & 0.783 & 0.601 & -0.905 & 0.892 & -0.892 \\
\hline B_Pinene & 0.216 & 0.016 & 0.068 & 1.000 & 0.085 & 0.048 & 0.159 & 0.435 & 0.193 & -0.237 & -0.092 \\
\hline o_Cymene & 0.895 & 0.865 & 0.987 & 0.085 & 1.000 & 0.865 & 0.810 & 0.637 & -0.941 & 0.929 & -0.882 \\
\hline B_Myrcene & 0.656 & 0.889 & 0.930 & 0.048 & 0.865 & 1.000 & 0.733 & 0.380 & -0.748 & 0.720 & -0.892 \\
\hline Sabinene & 0.517 & 0.476 & 0.783 & 0.159 & 0.810 & 0.733 & 1.000 & 0.191 & -0.807 & 0.743 & -0.960 \\
\hline 1_Penten_3_ol & 0.907 & 0.682 & 0.601 & 0.435 & 0.637 & 0.380 & 0.191 & 1.000 & -0.460 & 0.497 & -0.254 \\
\hline 2_Butenal_2_methyl & -0.788 & -0.731 & -0.905 & 0.193 & -0.941 & -0.748 & -0.807 & -0.460 & 1.000 & -0.995 & 0.842 \\
\hline a_Thujene & 0.809 & 0.747 & 0.892 & -0.237 & 0.929 & 0.720 & 0.743 & 0.497 & -0.995 & 1.000 & -0.788 \\
\hline Ethyl propanoate & -0.592 & -0.670 & -0.892 & -0.092 & -0.882 & -0.892 & -0.960 & -0.254 & 0.842 & -0.788 & 1.000 \\
\hline
\end{tabular}

Note. Values in white cells denote significant correlations at $\mathrm{p}<0.05$.

Table 9. P-values matrix of the correlation between the number of Apis mellifera visits and the volatiles organic compounds identified in hermaphrodite flowers (VHF) in five commercial types of melon

\begin{tabular}{|c|c|c|c|c|c|c|c|c|c|c|c|}
\hline \multicolumn{12}{|l|}{ P-Values Matrix } \\
\hline & VHF & Benzaldehyde & D_Limonene & B_Pinene & o_Cymene & B_Myrcene & Sabinene & 1_Penten_3_ol & 2_Butenal_2_methyl & a_Thujene & Ethyl_propanoate \\
\hline VHF & 1.000 & 0.043 & 0.035 & 0.702 & 0.015 & 0.204 & 0.347 & 0.009 & 0.089 & 0.017 & 0.268 \\
\hline Benzaldehyde & 0.043 & 1.000 & 0.004 & 0.955 & 0.034 & 0.019 & 0.393 & 0.179 & 0.135 & 0.121 & 0.191 \\
\hline D_Limonene & 0.035 & 0.004 & 1.000 & 0.889 & -0.023 & -0.003 & 0.092 & 0.259 & 0.010 & 0.017 & 0.017 \\
\hline B_Pinene & 0.702 & 0.955 & 0.889 & 1.000 & 0.867 & 0.914 & 0.773 & 0.439 & 0.731 & 0.676 & 0.858 \\
\hline o_Cymene & 0.015 & 0.034 & -0.023 & 0.867 & 1.000 & 0.033 & 0.071 & 0.223 & -0.008 & -0.002 & 0.023 \\
\hline B_Myrcene & 0.204 & 0.019 & -0.003 & 0.914 & 0.033 & 1.000 & 0.134 & 0.503 & 0.121 & 0.145 & 0.017 \\
\hline Sabinene & 0.347 & 0.393 & 0.092 & 0.773 & 0.071 & 0.134 & 1.000 & 0.733 & 0.074 & 0.125 & -0.016 \\
\hline 1_Penten_3_ol & 0.009 & 0.179 & 0.259 & 0.439 & 0.223 & 0.503 & 0.733 & 1.000 & 0.410 & 0.370 & 0.655 \\
\hline 2_Butenal_2_methyl & 0.089 & 0.135 & 0.010 & 0.731 & -0.008 & 0.121 & 0.074 & 0.410 & 1.000 & -0.025 & 0.049 \\
\hline a_Thujene & 0.072 & 0.121 & 0.017 & 0.676 & -0.002 & 0.145 & 0.125 & 0.370 & -0.025 & 1.000 & 0.088 \\
\hline Ethyl_propanoate & 0.268 & 0.191 & 0.017 & 0.858 & 0.023 & 0.017 & -0.016 & 0.655 & 0.049 & 0.088 & 1.000 \\
\hline
\end{tabular}

Note. Values in white cells denote significant correlations at $\mathrm{p}<0.05$.

D-Limonene, Benzaldehyde and O-Cymene correlated positively and $\alpha$-Pinene correlated negatively to the number of honey bee visits to male flowers, while for hermaphrodite flowers the three compounds listed above 
plus $\alpha$-Thujene and 1_Penten_3_ol correlated positively (Tables 10 and 11). No compound showed negative correlation with bee visits to hermaphrodite flowers.

Table 10. Correlation between the number of Apis mellifera visits and the main volatile compounds identified in male flowers (VMF) in five commercial types of melon

\begin{tabular}{lllllllll}
\hline & $\beta$-Pinene & $\alpha$-Thujene & D-Limonene & Benzaldehyde & Sabinene & o-Cymene & Camphene & $\alpha$-Pinene \\
\hline VMF & -0.38 & 0.57 & $* * 0.92$ & $* * 0.91$ & 0.67 & $0.99^{* *}$ & -0.09 & ${ }^{* *}-0.95$ \\
\hline
\end{tabular}

Note. $*$ and $* *$ denote significant correlations at $\mathrm{p}<0.05$ and at $\mathrm{p}<0.01$, respectively.

Table 11. Correlation between the number of Apis mellifera visits and the main volatile compounds identified in hermaphrodite flowers (VHF) in five commercial types of melon

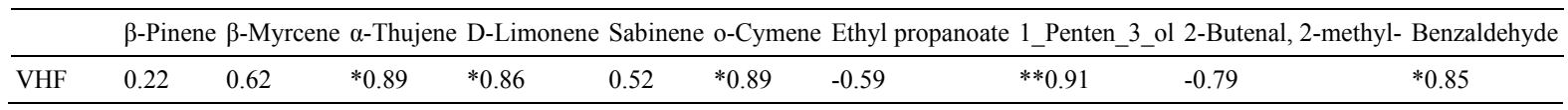

Note. ${ }^{*}$ and ${ }^{* *}$ denote significant correlations at $\mathrm{p}<0.05$ and at $\mathrm{p}<0.01$, respectively.

The profile of these VOCs showed significant differences between melon types and may explain the preference honey bees presented for visiting flowers of some melon types (Figure 2). Cantaloupe was the only melon type with low amounts of $\alpha$-Pinene in male flowers, the only significantly bee repellent for this flower gender, producing 2.5 times less than flowers of all other melon types. Cantaloupe male flowers also produced the greatest amount of D-Limonene, Benzaldehyde and O-Cymene, the three compounds in male flowers that were significantly attractant to honey bees (Figure 2a). The other melon types showed similar profiles among their male flowers with high amounts of $\alpha$-Pinene, and D-Limonene as the most abundant attractant VOC, though in small amounts, but much greater in the Piel de sapo and Charentais than Yellow and Galia. They also presented variable low amounts or absence O-Cymene and no Benzaldehyde, except for the Galia which had a tiny amount (Figures 2b-2e).

In respect to hermaphrodite flowers, again those produced by the Cantaloupe type stood well apart from flowers of the other types. They showed the highest amounts of D-Limonene, Benzaldehyde, o-Cymene, $\alpha$-Thujene and 1_Penten_3_ol, the compounds positively correlated to bee visits, in comparison to the other melon types (Figure 2a). Also, the only repellent compound present in these flowers was $\alpha$-Pinene, but unlike male flowers, this compound was not significantly correlated to bee visits in hermaphrodite flowers. Hermaphrodite flowers of the Yellow melon type produced a VOC profile similar to that of Piel de sapo and Galia, but richer in the attractants D-Limonene and Benzaldehyde and no significant repellent compound (Figures 2b-2d). Piel de sapo and Galia hermaphrodite flowers besides producing less D-Limonene and Benzaldehyde, also emitted 2-Butenal 2-methyl-, a bee-repellent compound but not significantly correlated to bee visits to hermaphrodite flower. The hermaphrodite flowers of Charentais presented a unique VOC profile. Unlike flowers of all the other melon types, these flowers produced little $\alpha$-Pinene, some D-Limonene (bee attractant) and 2-Butenal 2-methyl- (bee repellent). However, the predominant VOC by far was Ethyl acetate (Figure 2e). Although this compound did not show correlation to bee visitation to melon hermaphrodite flowers, Ethyl acetate is an effective insect repellent due to its asphyxiant properties and it may act as a pest and pollinator repellent in this particular melon type. Ethyl acetate was also found among the VOCs of the hermaphrodite flowers of Piel de sapo and Galia types, but in much smaller amounts (Figures $2 \mathrm{c}$ and $2 \mathrm{~d}$ ). 

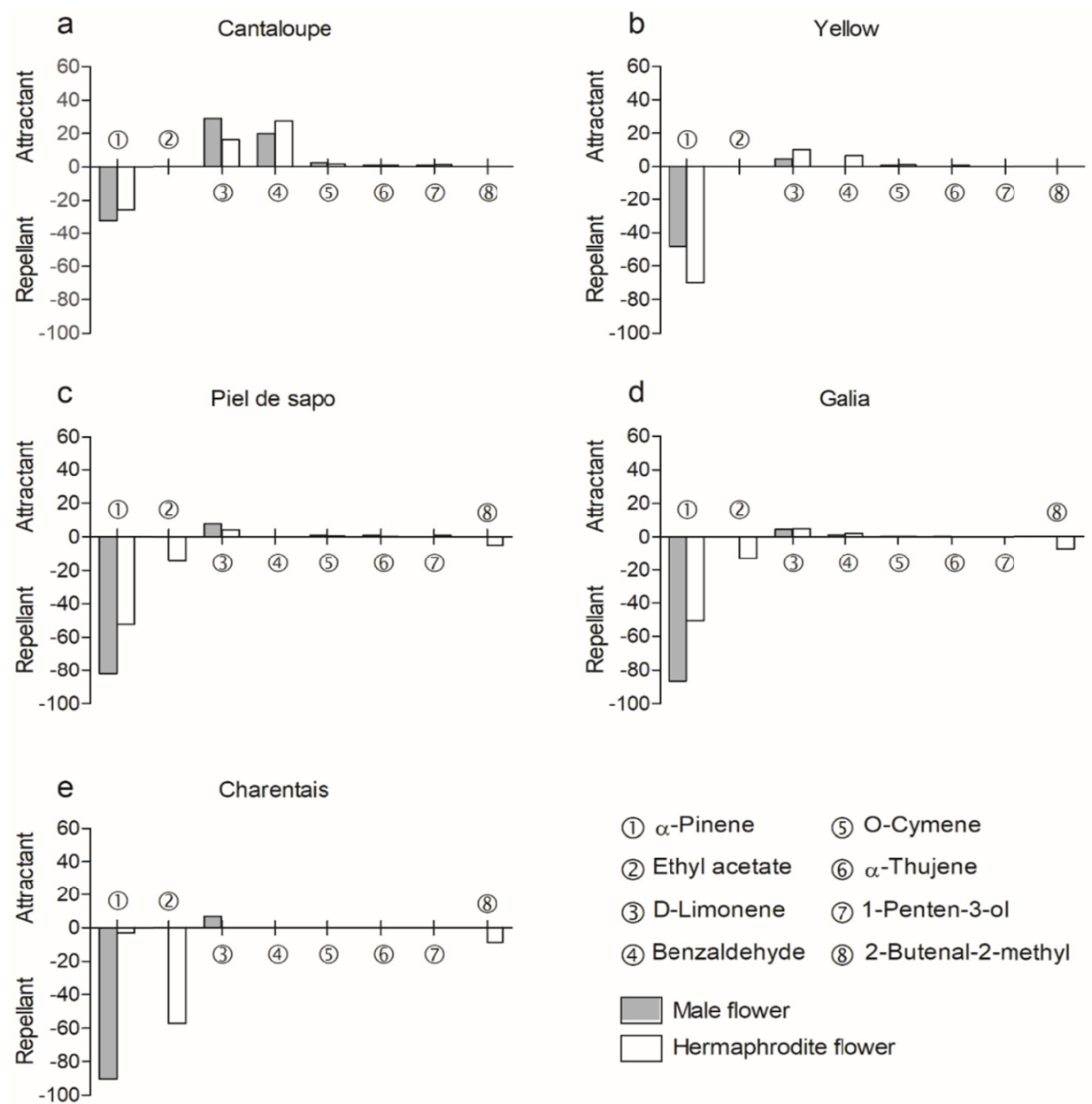

Figure 2. Identity and relative percentages of the main organic volatile compounds area found in male and hermaphrodite flowers of five commercial types of melon bearing attractive or repellent action to Apis mellifera foragers. Positive values denote attraction and negative values denote repellency

\section{Discussion}

Floral aromas usually are elaborate mixtures composed of volatile substances of various chemical groups, the most common being mono- and sesquiterpenoids, benzene, as well as groups such as alcohols, aldehydes, esters, ethers and ketones (Knudsen et al., 2006). Indeed, our study identified compounds from all these chemical groups in the odor of melon flowers, but it also showed that the VOCs of the terpene group predominated as the most important ones both in number and amount of compounds produced by the flowers. The terpenes are also the most abundant compounds in flowers of many plant species, especially those pollinated by bees (Dudareva \& Pichersky, 2006; Knudsen et al., 2006; Klatt et al., 2013). Therefore, it is reasonable to suppose the terpenes probably play a relevant role for the flower-pollinator relationships in the melon pollination process. Despite the predominance of the terpenes, other chemical groups have also contributed in lower numbers to the VOCs produced by melon flowers, but sometimes in great amounts like the ester Ethyl Acetate in the hermaphrodite Charentais flowers.

The composition and role of floral odors is complex, with some plant species exhibiting compounds with both attractive function (Chen et al., 2009) and defensive/repellent (Junker \& Bluthgen, 2010) for visitors/pollinators. In melon, we found that some of the VOCs identified in the flowers of the different agronomic types are proven attractive to bees, as is the cases with Benzyl alcohol (Wadhams et al., 1994; Knudsen et al., 2006), Methyl benzoate (Williams \& Whitten, 1983), Methyl salicylate (Williams \& Whitten, 1983; Knudsen et al., 2006; Dotterl \& Vereecken, 2010), O-Cymene (Granero et al., 2005; Knudsen et al., 2006), $\alpha$-Terpinene (Blight et al., 1997), Terpineol (Williams \& Whitten, 1983), D-limoneno, benzaldeído, mirceno and $\beta$-pineno (Knudsen et al., 2006; Junker \& Bluthgen, 2010; Klatt et al., 2013). Other compounds have shown repellent function, as in the case of acetophenone from the ketone group (Ceuppens et al., 2015), $\alpha$-Pinene, which bears pesticide and 
insecticide properties (Mercier, Prost, \& Prost, 2009), Ethyl acetate, an effective asphyxiant used in killing jars for insect collecting (Arnett, 2000) and, intriguingly, 2-Butenal 2-methyl-, a mammary pheromone used by lactating female rabbits (Schaal et al., 2003).

Although all melon types studied here belong to the same species, Cucumis melo, flowers of the distinct agronomic types presented a variable VOC profile, and their participation in the melon floral aroma varied considerably among flowers of the different types of melon, from 23 substances in an intricate blend in hermaphrodite flowers of the Cantaloupe type down to only three compounds representing $100 \%$ VOC emitted by Charentais male flowers. This may have influenced bee foraging because the presence or absence of some volatile compounds may change the level of attractiveness of the flowers (Ceuppens et al., 2015). In addition, differences in the relative proportion of VOCs emitted by flowers may affect the behavior of pollinators (Wright \& Schiestl, 2009). Ceuppens et al. (2015), for example, comparing the attractiveness of two varieties of strawberry to Bombus terrestris, reported that acetophenone was present in greater quantity in the variety that was less attractive to bees. In our study, however, acetophenone was found only in the Cantaloupe melon, in lower values. This concentration was probably not sufficient to affect the attractiveness of the flowers to $A$. mellifera, since the Cantaloupe was the melon type which received most visits. However, we found similar result to that described by Ceuppens et al. (2015) in respect to $\alpha$-Pinene (repellent) in melon male flowers. Melon types with less $\alpha$-Pinene were more visited. Despite the fact that male flowers do not produce fruits, their ability to attract pollinators is important for yield because they are the source of most pollen in a melon crop and also make the field more rewarding to foragers than it would be if they visit only hermaphrodite flowers, thus attracting more bees and promoting better pollination (Free, 1993; Freitas, 1995). Also, the number of flowers produced per day by each type of melon could affect its attractiveness to bees, so that those types that produce more flowers could be more visited. However, it does not seem to be the case here, because the hybrids studied do not differ in the number of flowers they produce per day nor in the total number of flowers per cycle (Fernandes, 2017).

It is possible that the Cantaloupe flowers were the most visited by the bees not only because they have little acetophenone but also because of less $\alpha$-Pinene than the others melon types and also because it was the one which produced greater amount of D-Limonene (attractant) and the greatest variety of VOCs, strengthening suggestions from studies with other crops that the resulting blend of VOCs may be determinant to the bee's choice (Pham-Delegue et al., 1989; Wright et al., 2002; Sachse \& Galizia, 2003; Klatt et al., 2013). Therefore, a mixture of more bee-attractant compounds and less bee-repellent VOCs seem to determine the role of floral odor in bee visits to melon flowers. However, in general $\alpha$-Pinene was the most abundant compound in the melon floral odor and it may be related to reports by growers and beekeepers that the melon crop is little attractive to honeybees. Melon breeders should consider flower VOC profile in breeding new varieties to make them more attractive or less repellent to pollinators.

Identification of the most important VOCs in the attractiveness of pollinators may be applicable to solve problems of modern agriculture, such as the pollinator deficit in agricultural areas and the lack of attractiveness of some crops to pollinators (Free, 1993; Vaissière, Freitas, \& Gemmill-Herren, 2011). Studies on sensory mechanisms, recognition, distinction of odors and preferences of pollinators in conjunction with floral resources, can also provide information on plant-pollinator interaction. However, it is necessary to analyze the specific differences between the plant species, identifying the most important VOCs within the complex mixture that is the floral odor, and to perform electrophysiological and behavioral tests to obtain an individual response of each VOC (Riffell et al., 2013; Byers et al., 2014).

Finally, the floral odor should be investigated as a floral attribute that together with other characteristics such as morphometry, color, texture, reflectance, electric field and rewards (Dafni \& Kevan, 1997; Alcorn et al., 2012; Clarke et al., 2013; Varassin \& Amaral-Neto, 2014) act on the attraction of pollinators to flowers, but whose small variations between plant species, and even varieties or types within of the same species, can produce distinct results making the flower of one more or less attractive than the other, or even losing the ability to attract pollinators. The complex plant-pollinator interaction through floral attractants is a promising field for the ecology and breeding of agricultural crops.

Our study allows to conclude that the floral VOC profile of the distinct agronomic melon types varies greatly both in the identity and proportion of the compounds and these differences can be, at least partially, responsible for the preferences shown by Apis mellifera to visit flowers of some melon types in relation to others. Melon flowers emitting more bee-attractant and less bee-repellent compounds are favoured by the bees, which in pollinator-dependent crop such as melon can have major implications to pollination and fruit yield. Finally, these findings point out the need of differentiated management of bee colonies according to the type of melon 
cultivated (more or less attractive to the bees), but also to the perspective of breeding varieties more attractive to pollinators through the selection of flower lines richer in bee-attractant and/or poorer in bee-repellent volatiles.

\section{Acknowledgements}

Breno M. Freitas and Fernando A. S. Aragão thanks CNPq for Research Productivity Fellowships (302934/2010-3 and 312139/2017-9, respectively).

\section{References}

Adams, R. P. (2007). Identification of Essential Oil Components by Gas Chromatography/Mass Spectrometry (4th ed.). Carol Stream, Illinois: Allured Publishing Corporation.

Aizen, M. A., \& Harder, L. D. (2007). Expanding the limits of the pollen-limitation concept: Effects of pollen quantity and quality. Ecology, 88(2), 271-281. https://doi.org/10.1890/06-1017

Alcorn, K., Whitney, H., \& Glover, B. (2012). Flower movement increases pollinator preference for flowers with better grip. Functional Ecology, 26(4), 941-947. https://doi.org/10.1111/j.1365-2435.2012.02009.x

Andrews, E. S., Theis, N., \& Adler, N. L. (2007). Pollinator and herbivore attraction to Cucurbita floral volatiles. Journal of Chemical Ecology, 33(9), 1682-691. https://doi.org/10.1007/s10886-007-9337-7

Arimura, G., Matsui, K., \& Takabayashi, J. (2009). Chemical and molecular ecology of herbivore-induced plant volatiles: Proximate factors and their ultimate functions. Plant and Cell Physiology, 50(5), 911-23. https://doi.org/10.1093/pcp/pcp030

Arnett, R. H. (2000). American insects: A handbook of the insects of America north of Mexico (2nd ed.). Boca Raton, Fl: CRC Press. https://doi.org/10.1201/9781482273892

Bezerra, A. D. M. (2014). Uso da abelha canudo (Scaptotrigona sp. nov.) na polinização do meloeiro (Cucumis melo L.) em ambiente protegido (Master's dissertation, Universidade Federal do Ceará. Fortaleza, Brazil). Retrieved from http://www.repositorio.ufc.br/handle/riufc/17097

Blight, M. M., Métayer, M. L., Delègue, M. P., Pickett, J. A., Marion-Poll, F., \& Wadhams, L. J. (1997). Identification of floral volatiles involved in recognition of oilseed rape flowers, Brassica napus, by honeybees, Apis mellifera. Journal of Chemical Ecology, 23(7), 1715-1727. https://oi.org/10.1023/ B:JOEC.0000006446.21160.c1

Bomfim, I. G. A., Bezerra, A. D. M., Nunes, A. C., Freitas, B. M., \& Aragão. F. A. S. (2015). Pollination requirements of seeded and seedless mini watermelon varieties cultivated under protected environment. Pesquisa Agropecuária Brasileira, 50(1), 44-53. https://doi.org/10.1590/S0100-204X2015000100005

Bomfim, I. G. A., Freitas, B. M., Aragão. F. A. S., \& Walters, S. A. (2016). Pollination of cucurbit crops. In M. Pessarakli (Ed.), Handbook of Cucurbits: Growth, Cultural Practices, and Physiology (pp. 181-200). Boca Raton, Fl: CRC Press. https://doi.org/10.1201/b19233-16

Byers, K. J., Vela, J. P., Peng, F., Riffell, J. A., \& Bradshaw Jr, H. D. (2014). Floral volatile alleles can contribute to pollinator-mediated reproductive isolation in monkeyflowers (Mimulus). The Plant Journal, 80(6), 1031-1042. https://doi.org/10.1111/tpj.12702

Ceuppens, B., Ameye, M., Van Langenhove, H., Roldan-Ruiz, I., \& Smagghe, G. (2015). Characterization of volatiles in strawberry varieties 'Elsanta'and 'Sonata' and their effect on bumblebee flower visiting. Arthropod-Plant Interactions, 9(3), 281-287. https://doi.org/10.1007/s11829-015-9375-y

Chaplin-Kramer, R., Dombeck, E., Gerber, J., Knuth, K. A., Mueller, N. D., Mueller, M., ... Klein, A.-M. (2014). Global malnutrition overlaps with pollinator dependent micronutrient production. Proceedings of the Royal Society B: Biological Sciences, 281, 20141799. https://doi.org/10.1098/rspb.2014.1799

Chen, C., Song, Q., Proffit, M., Bessière, J., Li, Z., \& Hossaert-McKey, M. (2009). Private channel: A single unusual compound assures specific pollinator attraction in Ficus semicordata. Functional Ecology, 23(5), 941-950. https://doi.org/10.1111/j.1365-2435.2009.01622.x

Chittka, L., \& Raine, N. E. (2006). Recognition of flowers by pollinators. Current Opinion in Plant Biology, 9(4), 428-435. https://doi.org/10.1016/j.pbi.2006.05.002

Chittka, L., Thomson, J. D., \& Waser, N. M. (1999). Flower constancy, insect psychology, and plant evolution. Naturwissenschaften, 86(8), 361-377. https://doi.org/10.1007/s001140050636

Clarke, D., Whitney, H., Sutton, G., \& Robert, D. (2013). Detection and learning of floral electric fields by bumblebees. Science, 340(61128), 66-69. https://doi.org/10.1126/science.1230883 
Coelho, M. S., Kiill, L. H. P., Costa, N. D., Pinto, J. M., Feitoza, E. A., \& Lima Junior, I .O. (2012). Diversidade de visitantes florais em cultivo orgânico de meloeiro. Horticultura Brasileira, 30(2), 1081-1087.

Crisóstomo, J. R., \& Aragão, F. A. S. (2013). Melhoramento genético do meloeiro. In F. C. Vidal Neto, \& J. J. V. Cavalcanti (Eds.), Melhoramento genético de plantas no Nordeste (pp. 209-246), Brasília, Distrito Federal: Embrapa.

Dafni, A., \& Kevan, P. G. (1997). Flower size and shape: implications in pollination. Israel Journal of Plant Sciences, 45(2-3), 201-211. https://doi.org/10.1080/07929978.1997.10676684

Dotterl, S., \& Vereecken, N. J. (2010). The chemical ecology and evolution of bee-flower interactions: A review and perspectives. Canadian Journal of Zoology, 88(7), 668-697. https://doi.org/10.1139/Z10-031

Dudareva, N., \& Pichersky, E. (2006). Biology of floral scent. Boca Raton, FL: CRC Press, Taylor \& Francis Group.

FAO (Food and Agriculture Organization of the United Nations). (2018). Corporate statistical database-FAOSTAT: Producrion/Crops. Retrieved from http://www.fao.org/faostat/en/\#data/QC

Farré-Armengol, G. (2015). Biotic and abiotic factors that determine the emission of volatile organic compounds by flowers (PhD Thesis, Universitat Autònoma de Barcelona). Retrieved from https://ddd.uab.cat/pub/tesis/ 2015/hdl_10803_288049/gfa1de1.pdf

Farré-Armengol, G., Filella, I., Llusia, J., \& Peñuelas, J. (2015). Relationships among floral VOC emissions, floral rewards and visits of pollinators in five plant species of a Mediterranean shrubland. Plant Ecology and Evolution, 148(1), 90-99. https://doi.org/10.5091/plecevo.2015.963

Fernandes, N. S. (2017). Atração e visitação da abelha Apis mellifera a flores de cinco tipos comerciais de meloeiro (Cucumis melo) (Doctoral Thesis, Universidade Federal do Ceará. Fortaleza, Brazil). Retrieved from http://www.repositorio.ufc.br/handle/riufc/31843

Ferrari, M. J., Stephenson, A. G., Mescher, M. C., \& Moraes, C. M. (2006). Inbreeding effects on blossom volatiles in Cucurbita pepo subsp. Texana (Cucurbitaceae). American Journal of Botany, 93(12), 1768-1774. https://doi.org/10.3732/ajb.93.12.1768

Filley C. M., Halliday, W., \& Kleinschmidt-DeMasters, B. K. (2004). The effects of toluene on the central nervous system. Journal of Neuropathology \& Experimental Neurology, 63(1), 1-12. https://doi.org/ $10.1093 /$ jnen/63.1.1

Freitas, B. M. (1995). The pollination efficiency of foraging bees on apple (Malus domestica Borkh) and cashew (Anacardium occidentale L.) (PhD Thesis. University of Wales College of Cardiff, Cardiff, UK).

Freitas, B. M., Imperatriz-Fonseca, V. L., Medina, L. M., Kleinert, A. M. P., Galetto, L., Nates-Parra, G., \& Quezada-Euán, J. J. G. (2009). Diversity, threats and conservation of native bees in the Neotropics. Apidologie, 40(3), 332-346. https://doi.org/10.1051/apido/2009012

Freitas, B. M., Pacheco Filho, A. J. S., Andrade, P. B., Lemos, C. Q., Rocha, E. E. M., Pereira, N. O., ... Mendonça, K. S. (2014). Forest remnants enhance wild pollinator visits to cashew flowers and mitigate pollination deficit in NE, Brazil. Journal of Pollination Ecology, 12(4), 22-30.

Filella, I., Primante, C., Llusià, J., González, A. M. M., Seco, R., Farré-Armengol, G., ... Penuelas, J. (2013). Floral advertisement scent in a changing plant-pollinators market. Scientific reports, 3, 3434. https://doi.org/ $10.1038 /$ srep03434

Free, J. B. (1993). Insect Pollination of Crops (2nd ed.). London UK: Academic Press.

Garibaldi, L. A., Aizen, M. A., Klein, A.-M., Cunningham, S. A., \& Harder, L. D. (2011). Global growth and stability of agricultural yield decrease with pollinator dependence. Proceedings of the National Academy of Sciences of the United States of America, 108(14), 5909-5914. https://doi.org/10.1073/pnas.1012431108

Garibaldi, L. A., Steffan-Dewenter, I., Winfree, R., Aizen, M. A., Bommarco, R., Cunningham, S. A., ... Klein, A.-M. (2013). Wild pollinators enhance fruit set of crops regardless of honey bee abundance. Science, 339(6127), 1608-1611. https://doi.org/10.1126/science.1230200

Granero, A. M., González, F. J. E., Frenich, A. G., Sanz, J. M. G., \& Vidal, J. L. M. (2004). Single step determination of fragrances in Cucurbita flowers by coupling headspace solid-phase microextraction low-pressure gas chromatography tandem mass spectrometry. Journal of Chromatography A, 1045(1-2), 173-179. https://doi.org/10.1016/j.chroma.2004.06.026 
Granero, A. M., González, F. J. E., Sanz, J. M. G., \& Vidal, J. L. M. (2005). Analysis of biogenic volatile organic compounds in zucchini flowers: Identification of scent sources. Journal of Chemical Ecology, 31(10). https://doi.org/10.1007/s10886-005-7103-2

Holopainen, J. K., \& Gershenzon, J. (2010). Multiple stress factors and the emission of plant VOCs. Trends in Plant Science, 15(3), 176-184. https://doi.org/10.1016/j.tplants.2010.01.006

Howell, A. D., \& Alarcon, R. (2007). Osmia bees (Hymenoptera: Megachilidae) can detect nectar-rewarding flowers using olfactory cues. Animal Behaviour, 74(2), 199-205. https://doi.org/10.1016/j.anbehav. 2006.11.012

Hoz, J. C. T. (2007). Visita de abejas (Apis mellifera, Hymenoptera: Apoidea) a flores de melón Cucumis melo (Cucurbitaceae) en Panamá. Revista de Biología Tropical, 55(2), 677-680.

IPBES (Intergovernmental Science-Policy Platform on Biodiversity and Ecosystem Services). (2016). In S. G. Potts, V. L. Imperatriz-Fonseca, H. T. Ngo, J. C. Biesmeijer, T. D. Breeze, L. V. Dicks ... B. F. Viana (Eds.), Summary for Policymakers of the Assessment Report of the Intergovernmental Science-Policy Platform on Biodiversity and Ecosystem Services on Pollinators, Pollination and Food Production. Bonn, Germany.

Junker, R. R., \& Bluthgen, N. (2010). Floral scents repel facultative flower visitors, but attract obligate ones. Annals of Botany, 105(5), 777-782. https://doi.org/10.1093/aob/mcq045

Kiill, L. H. P., Coelho, M. S., Siqueira, K. M. M., \& Costa, N. D. (2011). Avaliação do padrão de visitação de Apis mellifera em três cultivares de meloeiro, em Petrolina-PE, Brasil. Revista Brasileira de Fruticultura, 33, 455-460. https://doi.org/10.1590/S0100-29452011000500060

Kiill, L. H. P., Siqueira, K. M. M., Coelho, M. S., Silva, T. A., Gama, D. R. S., Araújo, D. C. S., \& Pereira Neto, J. (2014). Frequency and foraging behavior of Apis mellifera in two melon hybrids in Juazeiro, state of Bahia, Brazil. Anais da Academia Brasileira de Ciências, 86(4), 2049-2055. https://doi.org/10.1590/ 0001-3765201420130376

Klatt, B. K., Burmeister, C., Westphal, C., Tscharntke, T., \& Von Fragstein, M. (2013). Flower volatiles, crop varieties and bee responses. PLoS ONE, 8(8), e72724. https://doi.org/10.1371/journal.pone.0072724

Klein, A.-M., Vaissière, B. E., Cane, J. H., Steffan-Dewenter, I., Cunningham, S. A., ... Tscharntke, T. (2007). Importance of pollinators in changing landscapes for world crops. Proceeding of the. Royal Society of London, Series B, Biological. Science, 274, 303-313. https://doi.org/10.1098/rspb.2006.3721

Knudsen, J. T., Eriksson, R., Gershenzon, J., \& Ståhl, B. (2006). Diversity and distribution of floral scent. The Botanical Review, 72(1). https://doi.org/10.1663/0006 8101(2006)72[1:DADOFS]2.0.CO;2

Kouonon, L. C., Jacquemart, A. L., Bi, A. I., Bertin, P., Baudoin, J. P., \& Dje, Y. (2009). Reproductive biology of the andromonoecious Cucumis melo subsp. Agrestis (Cucurbitaceae). Annals of Botany, 104(6), 1129-1139. https://doi.org/10.1093/aob/mcp196

Kunze, J., \& Gumbert, A. (2001). The combined effect of colour and odor on flower choice behavior of bumble bees in flower mimicry systems. Behavioral Ecology, 12(4), 447-456. https://doi.org/10.1093/beheco/ 12.4.447

Lautenbach, S., Seppelt, R., Liebscher, J., \& Dormann, C. F. (2012). Spatial and temporal trends of global pollination benefit. PLOS ONE, 7(4). https://doi.org/10.1371/journal.pone.0035954

Majetic, C. J., Raguso, R. A., \& Ashman, T. L. (2009). The sweet smell of success: Floral scent affects pollinator attraction and seed fitness in Hesperis matronalis. Functional Ecology, 23(3), 480-487. https://doi.org/ $10.1111 / \mathrm{j} .1365-2435.2008 .01517 . \mathrm{x}$

Mercier, B., Prost, J., \& Prost, M. (2009). The essential oil of turpentine and its major volatile fraction ( $\alpha$ - and $\beta$-pinenes): A review. International Journal of Occupational Medicine and Environmental Health, 22(4), 331-342. https://doi.org/10.2478/v10001-009-0032-5

Mussen, E. C., \& Thorp, R.W. (2003). Honey bee pollination of cantaloupe, cucumber and watermelon (Publication, 7224). Oakland: University of California, Division of Agriculture and Natural Resources. Retrieved from http://anrcatalog.ucanr.edu/pdf/ 7224.pdf

Myczko, L., Banaszak-Cibicka, W., Sparks, T. H., \& Tryjanowski, P. (2015). Do queens of bumblebee species differ in their choice of flower colour morphs of Corydalis cava (Fumariaceae)? Apidologie, 4(30), 337-345. https://doi.org/10.1007/s13592-014-0326-x 
Parachnowitsch, A. L., Raguso, R. A., \& Kessler, A. (2012). Phenotypic selection to increase floral scent emission, but not flower size or colour in bee-pollinated Penstemon digitalis. New Phytologist, 195, 667-675. https://doi.org/10.1111/j.1469-8137.2012.04188.x

Pascual, R., \& Bustamante, C. (2011). Structural neuroplasticity induced by melatonin in entorhinal neurons of rats exposed to toluene inhalation. Acta Neurobiologiae Experimentalis, 71(4), 541-547.

Pham-Delegue, M. H., Etievant, P., Guichard, E., \& Masson, C. (1989). Sunflower volatiles involved in honey bee discrimination among genotypes and flowering stages. Journal of Chemical Ecology, 15(1), 329-343. https://doi.org/10.1007/BF02027794

Pichersky, E., \& Gershenzon, J. (2002). The formation and function of plant volatiles: Perfumes for pollinator attraction and defense. Current Opinion in Plant Biology, 5(3), 237-243. https://doi.org/10.1016/S13695266(02)00251-0

Pitrat, M., Hanelt, P., \& Hammer, K., (2000). Some comments on infraspecific classification of cultivar of melon. Acta Horticulturae, 510, 29-36. https://doi.org/10.17660/ActaHortic.2000.510.4

Potts, S. G., Biesmeijer, J. C., Kremen, C., Neumann, P., Schweiger, O., \& Kunin, W. E. (2010). Global pollinator declines: Trends, impacts and drivers. Trends in Ecology and Evolution, 25(6), 345-353. https://doi.org/ $10.1016 /$ j.tree.2010.01.007

Raguso, R. A. (2008). Wake up and smell the roses: The ecology and Evolution of floral scent. Annual Review of Ecology, Evolution, and Systematics, 39, 549-69. https://doi.org/10.1146/annurev.ecolsys.38.091206.095601

Reyes-Carrillo, J. L., Eischen, F. A., Cano-Rios, P., Rodriguez-Martinez, R., \& Camberos, U. N. (2007). Pollen collection and honey bee forager distribution in cantaloupe. Acta Zoológica Mexicana, 23(1), 29-36.

Ribeiro, M. F., Silva, E. M. S., Lima Júnior, I. O., \& Kiill, L. H. P. (2015). Honey bees (Apis mellifera) visiting flowers of yellow melon (Cucumis melo) using different number of hives. Ciência Rural, 45(10), 1768-1773. https://doi.org/10.1590/0103-8478cr20140974

Ricketts, T. H., Regetz, J., Steffan-Dewenter, I., Cunningham, S. A., Kremen, C., Bogdanski, A., ... Viana, B. F. (2008). Landscape effects on crop pollination services: Are there general patterns? Ecology Letters, 11(5), 499-515. https://doi.org/10.1111/j.1461-0248.2008.01157.x

Riffell, J. A., Lei, H., Abrell, L., \& Hildebrand, J. G. (2013). Neural basis of a pollinator's buffet: Olfactory specialization and learning in Manduca sexta. Science, 339(6116), 200-204. https://doi.org/10.1126/ science. 1225483

Rodriguez-Saona, C., Parra, L., Quiroz, A., \& Isaacs, R. (2011). Variation in highbush blueberry floral volatile profiles as a function of pollination status, cultivar, time of day and flower part: implications for flower visitation by bees. Annals of Botany, 107, 1377-1390.

Rundlöf, M., Andersson, G. K., Bommarco, R., Fries, I., Hederström, V., Herbertsson, L., ... Smith, H. G. (2015). Seed coating with a neonicotinoid insecticide negatively affects wild bees. Nature, 521(7550), 77-80.

Sachse, S., \& Galizia, C. G. (2003).The coding of odour intensity in the honeybee antennal lobe: local computation optimizes odour representation. European Journal of Neuroscience, 18(8), 2119-2132.

Schaal, B., Coureaud, G., Langlois, D., Ginles, C., Semon, E., \& Perrier, G. (2003). Chemical and behavioural characterization of the rabbit mammary pheromone. Nature, 424, 68-72.

Schiestl, F. P. (2010). The evolution of floral scent and insect chemical communication. Ecology Letters, 13(5), 643-656.

Silva, F. A. N., Silva, A. A., Fernandes, N. S., Rodrigues, T. H. S., Nascimento, R. F., Brito, ... Zocolo, G. J. (2018). Evaluation of headspace solid-phase microextraction gas chromatography-mass spectrometry for the characterization of volatile organic compounds from melon (Cucumis melo L.) flowers. Chromatographia, 81, 1231-1239. https://doi.org/10.1007/s10337-018-3550-0

Song, B., Chen, G., Stöcklin, J., Peng, D. L., Niu, Y., Li, Z. M., \& Sun, H. (2014). New pollinating seed-consuming mutualism between Rheum nobile and a fly fungus gnat, Bradysia sp., involving pollinator attraction by a specific floral compound. New Phytologist, 203(4), 1109-1118. https://doi.org/10.1111/ nph. 12856 
Soto, V. C., Maldonado, I. B., Jofré, V. P., Galmarini, C. R., \& Silva, M. F. (2015). Direct analysis of nectar and floral volatile organic compounds in hybrid onions by HS-SPME/GC-MS: Relationship with pollination an seed production. Microchemical Journal, 122, 110-118. https://doi.org/10.1016/j.microc.2015.04.017

Song, G. C., \& Ryu, C. (2013). Two volatile organic compounds trigger plant self-defense against a bacterial pathogen and a sucking insect in Cucumber under open field conditions. International Journal of Molecular Sciences, 14(5), 9803-9819. https://doi.org/10.3390/ijms14059803

Sousa, R. M., Aguiar, O. S., Freitas, B. M., Silveira Neto, A. A., \& Pereira, T. F. C. (2009). Requerimento de polinização do meloeiro (Cucumis melo L.) no município de Acaraú-CE-Brasil. Caatinga, 22(1), 238-242.

Suchet, C., Dormont, L., Schatz, B., Giurfa, M., Simon, V., Raynaud, C., \& Chave, J. (2011). Floral scent variation in two Antirrhinum majus subspecies influences the choice of naïve bumblebees. Behavioral Ecology and Sociobiology, 65(5), 1015-1027. https://doi.org/10.1007/s00265-010-1106-x

Tschoeke, P. H., Oliveira, E. E., Dalcin, M. S., Silveira-Tschoeke, M. C. A. C., \& Santos, G. R. (2015). Diversity and flower-visiting rates of bee species as potential pollinators of melon (Cucumis melo L.) in the Brazilian Cerrado. Scientia Horticulturae, 186, 207-216. https://doi.org/10.1016/j.scienta.2015.02.027

Ueda, H., Kikuta, Y., \& Matsuda, K. (2012). Plant communication, mediated by individual or blended VOCs? Plant Signaling \& Behavior, 7(2), 222-226. https://doi.org/10.4161/psb.18765

Vaissière, B. E., Freitas, B. M., \& Gemmill-Herren, B. (2011). Protocol to detect and assess pollination deficits in crops: A handbook for its use. Rome IT: FAO.

Vankar, P. S. (2004). Essential oils and fragrances from natural sources. Resonance, 9(4), 30-4.

Varassin, I. G., \& Amaral-Neto, L. P. (2014). Atrativos. In A. R. Rech, K. Agostini, P. E. Oliveira, \& I. C. Machado (Eds.), Biologia da polinização (pp. 151-170). Rio de Janeiro: Editora Projeto Cultural.

Vivaldo, G., Masi, E., Taiti, C., Caldarelli, G., \& Mancuso, S. (2017). The network of plants volatile organic compounds. Scientific Reports, 7(1), 11050. https://doi.org/10.1038/s41598-017-10975-x

Wadhams, L. J., Blight, M. M., Kerguelen V., Le Métayer, M., Marion-Poll, F., Masson, C., ... Woodcock, C. M. (1994). Discrimination of oilseed rape volatiles by honey bee: Novel combined gas chromatographicelectrophysiological behavioral assay. Journal of Chemical Ecology, 20(12), 3221-3231.

War, A. R., Paulraj, M. G., Ahmad, T., Buhroo, A. A., Hussain, B., Ignacimuthu, S., \& Sharma, H. C. (2012). Mechanisms of plant defense against insect herbivores. Plant Signaling \& Behavior, 7(10), 1306-1320. https://doi.org/10.4161/psb.21663

Whitney, H. M., Chittka, L., Bruce, T. J. A., \& Glover, B. J. (2009). Conical epidermal cells allow bees to grip flowers and increase foraging efficiency. Current Biology, 19(11), 948-53. https://doi.org/10.1016/ j.cub.2009.04.051

Williams, N. H., \& Whitten, W. M. (1983). Orchid floral fragrances and male euglossine bees: methods and advances in the last sesquidecade. The Biological Bulletin, 164(3), 355-395.

Wright, G. A., \& Schiestl, F. P. (2009). The evolution of floral scent: The influence of olfactory learning by insect pollinators on the honest signalling of floral rewards. Functional Ecology, 23(5), 841-851. https://doi.org/10.1111/j.1365-2435.2009.01627.x

Wright, G. A., Skinner, B. D., \& Smith, B. H. (2002). Ability of honeybee, Apis mellifera, to detect and discriminate odors of varieties of canola (Brassica rapa and Brassica napus) and snapdragon flowers (Antirrhinum majus). Journal of Chemical Ecology, 28(4), 721-740.

Yamada, Y., Ohtani, K., Imajoa, A., Izu, H., Nakamura, H., \& Shiraishi, K. (2015) Comparison of the neurotoxicities between volatile organic compounds and fragrant organic compounds on human neuroblastoma SK-N-SH cells and primary cultured rat neurons. Toxicology Reports, 2, 729-736. https://doi.org/10.1016/j.toxrep.2015.05.002

\section{Copyrights}

Copyright for this article is retained by the author(s), with first publication rights granted to the journal.

This is an open-access article distributed under the terms and conditions of the Creative Commons Attribution license (http://creativecommons.org/licenses/by/4.0/). 